\title{
Representing the EU in the area of CFSP: Legal and Political Dynamics
}

Citation for published version (APA):

Dijkstra, H., \& Van Elsuwege, P. (2018). Representing the EU in the area of CFSP: Legal and Political Dynamics. In S. Blockmans, \& P. Koutrakos (Eds.), Research Handbook on The EU's Common Foreign and Security Policy (pp. 44-64). Edward Elgar Publishing. https://doi.org/10.4337/9781785364082.00010

Document status and date:

Published: 01/12/2018

DOI:

10.4337/9781785364082.00010

Document Version:

Publisher's PDF, also known as Version of record

Document license:

Taverne

Please check the document version of this publication:

- A submitted manuscript is the version of the article upon submission and before peer-review. There can be important differences between the submitted version and the official published version of record.

People interested in the research are advised to contact the author for the final version of the publication, or visit the DOI to the publisher's website.

- The final author version and the galley proof are versions of the publication after peer review.

- The final published version features the final layout of the paper including the volume, issue and page numbers.

Link to publication

\footnotetext{
General rights Owners
rights.

- You may freely distribute the URL identifying the publication in the public portal. please follow below link for the End User Agreement:

www.umlib.nl/taverne-license

Take down policy

If you believe that this document breaches copyright please contact us at:

repository@maastrichtuniversity.nl

providing details and we will investigate your claim.
}

Copyright and moral rights for the publications made accessible in the public portal are retained by the authors and/or other copyright owners and it is a condition of accessing publications that users recognise and abide by the legal requirements associated with these

- Users may download and print one copy of any publication from the public portal for the purpose of private study or research.

- You may not further distribute the material or use it for any profit-making activity or commercial gain

If the publication is distributed under the terms of Article $25 \mathrm{fa}$ of the Dutch Copyright Act, indicated by the "Taverne" license above, 


\section{Representing the EU in the area of CFSP: legal and political dynamics Hylke Dijkstra and Peter van Elsuwege}

\section{INTRODUCTION}

When Serbia and Kosovo started a dialogue to improve bilateral cooperation in March 2011, the EU's High Representative for Foreign Affairs and Security Policy together with the officials in the European External Action Service (EEAS) were tasked with facilitating the process. ${ }^{1}$ When the crisis in Ukraine escalated in February 2014, following the earlier Maidan protests, the foreign ministers of France, Germany and Poland flew jointly to Kiev to mediate between the government and the opposition on behalf of the EU. ${ }^{2}$ When the Joint Comprehensive Plan of Action concerning the nuclear programme of Iran was reached in July 2015, the signatories included Iran, the permanent members of the UN Security Council, Germany and the EU. ${ }^{3}$

The EU is therefore represented on the international stage by different actors and different actor constellations. This applies not only to highly visible ad hoc attempts at conflict resolution, but also to permanent forms of diplomacy. EU representation, for example, varies across international organizations. ${ }^{4}$ Within international organizations, it can vary even across the different committees. ${ }^{5}$ Similarly, the upgrading of the approximately 140 EU delegations after the Treaty of Lisbon (2009) has taken place unevenly. The result is that these EU delegations perform very different functions depending on their location. The EU delegation in Baku is not the same as the one in

1 J Bergmann and A Niemann, 'Mediating International Conflicts: The European Union as an Effective Peacemaker?' (2015) 53 Journal of Common Market Studies 957.

2 Federal Foreign Office of Germany, 'Crisis diplomacy in Ukraine' (21 February 2014) <http://www.auswaertiges-amt.de/EN/Aussenpolitik/Laender/Aktuelle_Artikel/Ukraine/140219_ Ukraine.html> accessed 4 January 2016.

3 Joint Comprehensive Plan of Action (14 July 2015) <http://eeas.europa.eu/archives/docs/ statements-eeas/docs/iran_agreement/iran_joint-comprehensive-plan-of-action_en.pdf $>$ accessed 2 March 2017; see also Chapter 9 in this volume.

4 E.g. K Verlin Laatikainen and KE Smith (eds), The European Union at the United Nations: Intersecting Multilateralisms (Palgrave Macmillan 2006); KE Jørgensen (ed), The European Union and International Organizations (Routledge 2009); KE Jørgensen, S Oberthür and J Shahin (eds), 'The Performance of the EU in International Institutions' (2011) 33 Journal of European Integration 599; KE Jørgensen and $\mathrm{K}$ Verlin Laatikainen (eds), Routledge Handbook on the European Union and International Institutions: Performance, Policy, Power (Routledge 2013).

5 E.g. within the UN General Assembly, see K Verlin Laatikainen, 'The EU Delegation in New York: A Debut of High Political Drama' in D Spence and J Batora (eds), The European External Action Service: European Diplomacy Post-Westphalia (Palgrave Macmillan 2015) tables 10.1 and 10.2. 
Beijing. ${ }^{6}$ EU external representation thus varies significantly and it is not immediately clear why.

This chapter attempts to understand how the EU representation in the field of Common Foreign and Security Policy (CFSP) is organized and applied in practice. This question is hardly new. The issue of EU external representation has been at the heart of policy discussions about European foreign policy cooperation since at least the 1970s. And the academic literature discusses inter-institutional politics and the consequences for EU external representation. ${ }^{7}$ This chapter makes three contributions. First, it seeks to provide a comprehensive overview of EU external representation in the field of CFSP, whereas other publications focus on other areas or specific cases. Second, it approaches the question from a distinctly legal-political perspective, where others have stayed within disciplinary boundaries. Third, it focuses on the Treaty of Lisbon and the post-Lisbon era, whereas most of the scholarship is concerned with the pre-Lisbon institutional set-up of external representation.

This chapter starts by discussing EU external representation from a conceptual perspective. It outlines various legal and political dynamics behind the research question who represents the EU. It continues by analysing three instances of external representation: first, multilateral representation of the EU in international organizations and fora; second, bilateral representation of the EU in other countries; third, ad hoc representation and mediation attempts by the EU in international and regional conflicts. The conclusion sheds further light on the interaction between law and politics in understanding EU external representation.

6 R Balfour and K Raik, Equipping the European Union for the 21st Century: National Diplomacies, the European External Action Service and the Making of EU Foreign Policy (Finnish Institute of International Affairs 2013); F Austermann, European Union Delegations in EU Foreign Policy: A Diplomatic Service of Different Speeds (Palgrave Macmillan 2015); Spence and Batora (n 5).

7 E.g. D Allen, "Who Speaks for Europe?": The Search for an Effective and Coherent External Policy' in J Peterson and H Sjursen (eds), A Common Foreign Policy for Europe? Competing visions of the CFSP (Routledge 1998); S Meunier and K Nicolaidis, "Who Speaks for Europe? The Delegation of Trade Authority in the EU' (1999) 37 Journal of Common Market Studies 477; I Govaere, J Capiau and A Vermeersch, 'In-Between Seats: The Participation of the European Union in International Organisations' [2004] European Foreign Affairs Review 155; H Dijkstra, 'EU External Representation in Conflict Resolution: When Does the Presidency or the High Representative Speak for Europe?' (2011) 15 European Integration online Papers (EIoP) <http://eiop.or.at/eiop/texte/2011-001a.htm> accessed 24 February 2017; R Bengtsson and D Allen, 'Exploring a Triangular Drama: The High Representative, the Council Presidency and the Commission' in G Mueller-Brandeck-Bocquet and C Rueger (eds), The High Representative for the EU Foreign and Security Policy: Review and Prospects (Nomos 2011); E da Conceição-Heldt and S Meunier, 'Speaking With a Single Voice: Internal Cohesiveness and External Effectiveness of the EU in Global Governance' (2014) 21 Journal of European Public Policy 961; C Kaddous (ed), The European Union in International Organisations and Global Governance (Hart Publishing 2015). 


\section{EU EXTERNAL REPRESENTATION IN LAW AND POLITICS}

EU external representation can be studied through the disciplinary lenses of law and politics. The EU Treaties contain various legal provisions determining which actor represents the EU on which issue. Similarly, from a political perspective, one can examine the leadership of actors in EU external representation, their effectiveness and instances of bureaucratic politics. Rather than analysing legal rules and political dynamics separately, however, we study how they interact. The legal provisions in the Treaties are the result of political choices and many legal rules are codifications of previous norms and practices. Furthermore, political actors tend to use legal provisions to their advantage. This conceptual section starts with some historical background before outlining key legal aspects of the Treaty of Lisbon. It continues by pointing out how political science theories complement legal insights.

\subsection{Development of EU External Representation Prior to the Lisbon Treaty}

The first instances of external representation pre-date the establishment of the European Economic Community (EEC) with the Treaty of Rome in 1958. Jean Monnet, as President of the High Authority of the European Coal and Steel Community (ECSC), was keenly aware of the importance of transatlantic relations and opened an ECSC information office in Washington, DC in $1954 .{ }^{8}$ Over the next 50 years, the European Commission continued this practice and opened delegations around the world. Diplomatic relations were initially established with important trading partners and countries receiving development assistance. This reflected the EEC's competence in external commercial policy as well as the Commission's role in development cooperation following the Lomé agreements of the 1970s. By the time that the Treaty of Lisbon entered into force in 2009, the Commission had more than 130 delegations in non-member countries and international organizations. ${ }^{9}$

In parallel to the external representation of the EEC, there was a need to represent European Political Cooperation (EPC) established in 1970. The administration of EPC had been delegated to the six-monthly rotating Presidency. It was put in charge of external representation with the London Report of 1981. ${ }^{10}$ This arrangement was formally confirmed with the Single European Act (SEA). ${ }^{11}$ With the Treaty of Maastricht of 1993, EPC transformed into the CFSP as a separate 'pillar' of the EU.

8 European Commission, Taking Europe to the World: 50 Years of the European Commission's External Service (Office for Official Publications of the European Communities 2004).

9 M Bruter, 'Diplomacy Without a State: The External Delegations of the European Commission' (1999) 6 Journal of European Public Policy 183; D Spence, 'The European Commission's External Service' (2004) 19 Public Policy and Administration 61; European Commission (n 8); C Carta, The European Union Diplomatic Service: Ideas, Preferences and Identities (Routledge 2012); E Drieskens, 'What's in a Name? Challenges to the Creation of EU Delegations' (2012) 7 The Hague Journal of Diplomacy 51; Austermann (n 6).

10 S Nuttall, European Political Cooperation (Clarendon Press 1992); S Nuttall, European Foreign Policy (OUP 2000); ME Smith, Europe's Foreign and Security Policy: The Institutionalization of Cooperation (CUP 2004).

11 Single European Act [1987] OJ L169, Art. 30. 
Concomitantly, a purely intergovernmental system of cooperation became part of a legal system established by Treaty law. ${ }^{12}$ This was also visible with respect to external representation. Article J.5 of the Maastricht Treaty on European Union (TEU) not only articulated the role of the rotating Presidency and the supportive role of the incoming and preceding Presidencies under the so-called 'Troika' formula, but also explicitly provided that 'the Commission shall be fully associated in these tasks' ${ }^{13}$ Every subsequent amendment of the Treaties strengthened the incorporation of the CFSP in the EU legal order, while retaining its specific legal rules and institutional mechanisms.

The Treaty of Amsterdam of 1999 significantly developed the specific CFSP toolbox through the introduction of new instruments such as Common Strategies, Common Positions and Common Actions. Moreover, the revised Article 11 TEU clarified that the CFSP was no longer to be defined and implemented by 'the Union and its member states' but by the Union alone. ${ }^{14}$ This also implied significant amendments to the external representation of the CFSP. Even though the Council Presidency retained its formal representative function in this area, it was to be assisted by the SecretaryGeneral of the Council, who exercised the new function of 'High Representative for the Common Foreign and Security Policy'. ${ }^{15}$ It is no secret that the first High Representative, Javier Solana (1999-2009), often overshadowed the foreign ministers of the Presidency. ${ }^{16} \mathrm{He}$ was assisted by a Policy Unit as well as the officials of the Council Secretariat. The Council could also appoint Special Representatives with a mandate in relation to particular policy issues. ${ }^{17}$

Last but not least, the EU acquired the capacity to conclude international agreements in the field of CFSP, leading to a (largely academic) debate about the existence of the Union's international legal personality besides that of the European Community, which was explicitly foreseen in the EC Treaty. ${ }^{18}$ This discussion had already lost much of its practical relevance after the Treaty of Nice clarified that international agreements in the area of CFSP 'shall be binding on the institutions of the Union'. The abolition of the pillar structure and the express grant of a single legal personality to the Union with

\footnotetext{
12 See: R Gosalbo Bono, 'Some Reflections on the CFSP Legal Order' (2016) 43 CML Rev 341.

13 PJ Kuijper, J Wouters, F Hoffmeister, G De Baere and T Ramopoulos, The Law of EU External Relations: Cases, Materials and Commentary on the EU as an International Legal Actor (OUP 2013) 25.

14 As argued by Bono, 'the deletion of the reference to Member States meant that the Treaty of Amsterdam discarded this intergovernmental trait of the CFSP introduced by the Maastricht Treaty' (n 12) 348.

15 Art. 18(3) TEU (Amsterdam version); H Dijkstra, 'The Council Secretariat's Role in the Common Foreign and Security Policy’ (2008) 13 European Foreign Affairs Review 149.

16 Dijkstra (n 7).

17 Art. 18(5) TEU (Amsterdam version).

18 With regard to this academic discussion, see e.g. U Everling, 'Reflections on the Structure of the European Union' (1992) 29 CML Rev 1053; A von Bogdandy, 'The Legal Case for Unity: The European Union as a Single Organization with a Single Legal System' (1999) CML Rev 887; RA Wessel, 'Revisiting the International Legal Status of the EU' (2000) 5 European Foreign Affairs Review 507; R Leal-Arcas, 'EU Legal Personality in Foreign Policy?' (2006) 24 Boston University International Law Journal 165.
} 


\section{Research handbook on the EU's common foreign and security policy}

the Treaty of Lisbon finally put an end to all possible speculations. ${ }^{19}$ It is now crystal clear that the CFSP is an integral part of the autonomous EU legal order and not a separate framework of cooperation subject to general rules of international law.

\subsection{The Treaty Framework of EU External Representation}

The Lisbon Treaty aimed to enhance the effectiveness and coherence of the Union's external action..$^{20}$ The dissolution of the pillar structure (Art. 1 TEU), the introduction of a single legal personality for the Union (Art. 47 TEU) and the grouping of all external action principles and objectives - including those of the CFSP - in a single Chapter ${ }^{21}$ and a specific Treaty provision (Art. 21 TEU) give the impression of a fully integrated legal framework. ${ }^{22}$ At the institutional level, the new functions of a permanent European Council President (Art. 15 TEU), a double-hatted High Representative and Vice-President of the European Commission responsible for the consistency of external activities (Art. 18 TEU), assisted by the newly established EEAS (Art. 27 TEU) and Union delegations abroad (Art. 221 TFEU), confirm this picture.

However, upon closer inspection, it is clear that 'the proclaimed unity of EU external action only extends to its general principles and objectives' whereas the EU's competence in the field of CFSP remains clearly distinct from other categories of competence set out in the TFEU. ${ }^{23}$ Also in the post-Lisbon era, the CFSP remains 'subject to specific rules and procedures' (Art. 24 TEU) implying a predominant role for the institutions which are assimilated with the executive power (European Council and Council) and a limited possibility of judicial review. ${ }^{24}$ The distinctiveness of the CFSP is made explicit in the so-called mutual non-affect clause of Article 40 TEU. According to this provision, the implementation of the CFSP shall not affect the application of the procedures and the powers of the institutions laid down by the TFEU and vice versa. However, in the absence of clear criteria to define the scope of CFSP in relation to other fields of the Union's external action, there is significant potential for inter-institutional conflicts. ${ }^{25}$

The 'integration-delimitation' paradox is also reflected with respect to the EU's external representation. On the one hand, the role of the High Representative and the EEAS is to bridge the gap between CFSP and the other policy areas in an attempt to

19 Arts 1 and 47 TEU (Lisbon version).

20 See e.g. the Commission's statement on the occasion of the signature of the Lisbon Treaty, claiming that this new legal framework 'will enhance efficiency and give the Union a single voice in external relations' (IP/07/1922, 13 December 2007). For a critical analysis, see P Koutrakos, 'Primary Law and Policy in EU External Relations: Moving Away From the Big Picture' (2008) 33 EL Rev 666.

21 Chapter 1 of Title V of the TEU.

22 See also Chapter 1 in this volume.

23 Koutrakos (n 20) 669.

24 C Hillion, 'A Powerless Court? The European Court of Justice and the Common Foreign and Security Policy' in M Cremona and A Thies (eds), The European Court of Justice and External Relations Law: Constitutional Challenges (Hart Publishing 2014) 47.

$25 \mathrm{P}$ van Elsuwege, 'The Potential for Inter-Institutional Conflicts Before the Court of Justice: Impact of the Lisbon Treaty' in Cremona and Thies (n 24) 123. 
improve the coherence of the EU's external action. On the other hand, the limits of this integrated approach become obvious in the continued distinction of external representation tasks. The President of the European Council and the High Representative represent the Union for CFSP issues at their respective political levels whereas the Commission ensures external representation for the other policy areas. ${ }^{26}$

A similar institutional division between CFSP and non-CFSP external action is discernible with regard to the procedure for the negotiation and conclusion of international agreements and the adoption of Union positions in bodies set up by such agreements. ${ }^{27}$ Depending on the subject of the agreement (or position), the Commission or the High Representative can take the initiative. Reflecting the internal decisionmaking procedures, the role of the European Parliament in the procedure for concluding international agreements in the field of CFSP is limited to a right of information. ${ }^{28}$ In other words, the rules regarding the EU's external representation are concomitant with the internal division of powers and the constitutional principles on which the EU legal order is based. This implies, on the one hand, respect for the principles of conferral and institutional balance, implying that the Union and its institutions can only act within the limits of the competences conferred upon them in the Treaties, ${ }^{29}$ and, on the other hand, respect for the interconnected principles of sincere cooperation and consistency (or coherence), which mitigate (at least partially) the complexities following from the division of competences. ${ }^{30}$

\subsection{The Law and Politics of EU External Representation in Practice}

As the previous section shows, an analysis of the Treaty rules is not sufficient to understand the practice of the EU's external representation. It is equally important to outline some of the political dynamics at stake.

The first consideration is that of institutional choice. With the Lisbon Treaty, the Member States have established an advanced institutional framework, through which they can pursue common foreign and security policy on the international scene. The CFSP is, however, not the only framework. Most of the Member States still maintain unilateral diplomatic channels. In this respect, it is noteworthy that Declaration 13 to the Treaty of Lisbon underlines that the provisions on the CFSP "do not affect the responsibilities of the Member States ... for the formulation and conduct of their foreign policy nor of their national representation in third countries and international

\footnotetext{
26 Art. 15(6) TEU (President of the European Council); Art. 17 TEU (Commission) and Art. 27(2) TEU (High Representative).

27 Art. 218 TFEU.

28 See: Case C-658/11 European Parliament v Council (Pirate Transfer Agreement with Mauritius) EU:C:2014:2025 and comments in P van Elsuwege, 'Securing the Institutional Balance in the Procedure for Concluding International Agreements' (2015) 52 CML Rev 1379. See also Case C-263/14 European Parliament $v$ Council (Pirate Transfer Agreement with Tanzania) EU:C:2016:435.

29 Art. 5(2) TEU and Art. 13(2) TEU.

30 For comments, see: P van Elsuwege and H Merket, 'The Role of the Court of Justice in Ensuring the Unity of the EU's External Representation' in S Blockmans and RA Wessel (eds), Principles and Practices of EU External Representation (CLEER Working Papers 2012/5) 37.
} 


\section{Research handbook on the EU's common foreign and security policy}

organisations'. Declaration 14 further specifies that the CFSP 'will not affect the existing legal basis, responsibilities and powers of each Member State in relation to the formulation and conduct of its foreign policy, its national diplomatic service, relations with third countries and participation in international organisations'. The existence of an explicit EU competence in the area of CFSP (Art. 2(4) TFEU) therefore does not prevent the Member States from deploying their national foreign policy instruments.

The Member States are furthermore also bound by their commitments to other international organizations. The UN is a key example and the special responsibilities of France and the United Kingdom in the Security Council are broadly recognized. On issues of security and defence, NATO is furthermore the primary locus of choice for most Member States. ${ }^{31}$ While the Member States may be happy to support the High Representative and EEAS in general, not all Member States may be happy to support them on all issues. The politics behind institutional choice are interesting as they contrast a functional (which institutional framework can best address the problem?) and political logic (which institutional framework would best serve the interests of a Member State?) with the EU obligations of loyal cooperation. ${ }^{32}$

The Court of Justice has clarified the implications of the loyalty principle, as expressed in Article 4(3) TEU, with respect to the EU's non-CFSP external action. In essence, the duty of loyal cooperation implies that Member States may not undermine 'a concerted Union strategy' while expressing their national position in international fora. ${ }^{33}$ Significantly, such a strategy does not require the adoption of a legally binding document. As soon as a matter is discussed within the EU institutions, and even before the formal EU decision-making process enters into force, Member States are subject to special duties of action (i.e. actively supporting the EU's position) and abstention (i.e. refraining from the adoption of positions or actions undermining the EU's position or internal decision-making process). Significantly, the Member States' obligations are of general application, irrespective of whether the EU's competence is of an exclusive or shared nature. ${ }^{34}$

The question, of course, is to what extent these obligations in relation to the EU's non-CFSP external action apply equally to EU representation in the field of CFSP. Reflecting the special status of the CFSP, a specific duty of cooperation is maintained in Article 24(3) TEU. This seems at first sight a redundant repetition taking into account the horizontal nature of the EU's principles and objectives and the mandatory language used in defining the Member States' obligations of loyalty in the field of CFSP. Pursuant to Article 24(3), the Member States 'shall support' the Union's external and security policy, they 'shall comply' with the Union's action in this area and 'shall refrain' from any action that is contrary to the Union's interests or is likely to impair the effectiveness of its international action as a cohesive external actor.

31 'Shared Vision, Common Action: A Stronger Europe. A Global Strategy for the European Union's Foreign And Security Policy' (European External Action Service 2016) 20 <http://www.iss.europa.eu/uploads/media/EUGS.pdf> accessed 24 February 2017.

32 J Jupille, W Mattli and D Snidal, Institutional Choice and Global Commerce (CUP 2013); JC Morse and RO Keohane, 'Contested Multilateralism' [2014] The Review of International Organizations 385.

33 Case C-246/07 Commission v Sweden ECLI:EU:C:2010:203, para 103.

34 ibid, para 71. 
Moreover, the text leaves little scope for exceptions as suggested by the expressions 'actively' and 'unreservedly'. ${ }^{35}$ Article 28(2) TEU further specifies that CFSP decisions 'commit the Member States in the positions they adopt and in the conduct of their activity'. Consequently, it appears that the importance of the distinction between the general principle of loyal or sincere cooperation under Article 4(3) TEU and its CFSP-specific variant under Article 24(3) TEU should not be overestimated. A noticeable difference, of course, is that the Council and the High Representative rather than the Commission - shall ensure compliance with the loyalty principle in the field of CFSP. Whereas Article 24 TEU thus precludes the Commission from bringing a Member State before the Court of Justice for breaching its duties under the CFSP, Member State actions jeopardizing the attainment of the Union's external action objectives nevertheless fall within the Court's jurisdiction in the light of Article 4(3) TEU. 36

The second consideration is the control of the High Representative and the EEAS. It is well known in political science and international relations that the delegation of tasks likely results in an agency problem. ${ }^{37}$ In layman's terms: the High Representative and the EEAS have ideas of their own and may want to pursue those against the interests of some of the Member States. The Member States are therefore likely to keep the High Representative and the EEAS weak, under-staffed and subject to a whole range of oversight and accountability mechanisms. ${ }^{38}$ Furthermore, they are likely to bypass the High Representative and the EEAS if they anticipate that both EU actors will not effectively deliver on areas they consider important. A report of the UK House of Lords European Committee was quite explicit in this respect, when it stated that '[t]he EEAS should not ... seek to project its own foreign policy. The Common Foreign and Security Policy should remain under the control of the Member States.' 39

To better understand this so-called agency problem, it is necessary to identify first what the High Representative and the EEAS want to achieve. It is useful to distinguish between institutional interests and policy interests. In terms of institutional interests, there have been significant struggles between High Representatives and other EU actors. Javier Solana, Catherine Ashton and Federica Mogherini have all had their

35 C Hillion and RA Wessel, 'Restraining External Competences of the Member States under CFSP' in M Cremona and B De Witte (eds), EU Foreign Relations Law: Constitutional Fundamentals (Hart Publishing 2008) 91.

36 C Hillion, 'Cohérence et action extérieure de l'Union' in E Neframi (ed), Objectifs et compétences de l'Union européenne (Bruylant 2012); see also Hillion (n 24).

37 R Kiewiet and M McCubbins, The Logic of Delegation: Congressional Parties and the Appropriations Process (Chicago University Press 1991); M Pollack, The Engines of European Integration: Agency, Delegation, and Agenda Setting in the EU (OUP 2003); D Hawkins, D Lake, D Nielson and M Tierney (eds), Delegation and Agency in International Organizations (CUP 2006); CA Bradley and JG Kelley, 'The Concept of International Delegation' (2008) 71 Law and Contemporary Problems 1.

38 H Dijkstra, Policy-Making in EU Security and Defence Policy: An Institutional Perspective (Palgrave Macmillan 2013); H Dijkstra, International Organizations and Military Affairs (Routledge 2016).

39 European Union Committee, The EU's External Action Service (HL 2012-13, 147) $<$ http://www.publications.parliament.uk/pa/ld201213/ldselect/ldeucom/147/147.pdf> accessed 24 February 2017. 


\section{Research handbook on the EU's common foreign and security policy}

challenges with the Member States, the rotating Presidency and the European Commission. ${ }^{40}$ In terms of policy interest, the EU Treaties are an important guide. ${ }^{41}$ Furthermore, the High Representative and the EEAS have tried to pursue policies in which they have strengths. It is therefore no surprise that they have prioritized non-traditional threats, conflict prevention and the comprehensive approach, stressing the EU's unique crisis toolkit. ${ }^{42}$ This has not always pleased the Member States. They notably complained about the disinterest of Ashton in defence, including her skipping a ministerial meeting in 2010.43

The High Representative and the EEAS can only pursue interests different from those of the Member States if they have sufficient resources. Informational advantages are critically important in this respect. ${ }^{44}$ The Member States accept EU-level representation precisely because they cannot carry out all representative functions themselves. As a result of direct EU representation, Member States lose the ability to control all the interactions that the EU representative has with foreign counterparts. After all, they may not be privy to those interactions. Furthermore, few Member States rival the diplomatic network of the EEAS. This gives the EEAS insight about many third countries. The EEAS has also significant in-house expertise and serves as the point of contact for many third parties. These advantages allow the High Representative and the EEAS to pursue their interests.

Member States are keenly aware of this agency problem. They have installed a range of control mechanisms. It is common practice to distinguish between ex ante and ex post control mechanisms. The former determine the scope and procedure of a delegated task, while the latter are about the monitoring and sanctioning of the High Representative and the EEAS. ${ }^{45}$ EU statements, for example, need to be cleared with the Member States. The EEAS and its delegations are packed with national diplomats. Changes to the budget, personnel policy or organization of the EEAS furthermore need to be cleared with the Member States. Control and oversight are not necessarily explicit. The High Representative and the EEAS typically anticipate that the Member States may be unhappy with their actions and thus refrain from such actions in the first place. They are responsive to the wishes of the membership.

40 H Dijkstra, 'Commission Versus Council Secretariat: An Analysis of Bureaucratic Rivalry in European Foreign Policy' (2009) 14 European Foreign Affairs Review 431; Mueller-BrandeckBocquet and Rueger (n 7); N Helwig and C Rueger, 'In Search of a Role for the High Representative: The Legacy of Catherine Ashton' (2014) 49 International Spectator 1.

41 Arts 3(2), 21 TEU.

42 European Council, A Security Europe in a Better World: European Security Strategy (12 December 2003) <https://europa.eu/globalstrategy/en/european-security-strategy-secure-europebetter-world> accessed 17 February 2017; S Vanhoonacker and K Pomorska, 'The European External Action Service and agenda-setting in European foreign policy' (2013) 20 Journal of European Public Policy 1316.

43 V Pop, 'Ashton's absence from defence gathering raises eyebrows' (EUObserver, 25 February 2010) <https://euobserver.com/news/29552> accessed 22 February 2017.

44 Pollack (n 37); Hawkins and others (n 37).

$45 \mathrm{~T}$ Delreux and J Adriaensen, 'Introduction' in $\mathrm{T}$ Delreux and $\mathrm{J}$ Adriaensen (eds), The Principal-Agent Model and the European Union (Palgrave 2017). 
The final consideration is one of bureaucratic politics. This goes a step further than the question of control. Member States may well be in agreement that it is better to be represented by the High Representative and the EEAS in a particular area of the CFSP. Yet this logic may run into trouble when considering the parochial interests within the Member States. In particular, the emergence of the High Representative and the EEAS challenges the foreign ministers and the national diplomatic services, respectively. We know that institutions are sticky:46 they tend to survive even if there is no explicit purpose for them. This can also be said regarding certain tasks of national diplomatic services. Typically among the most prestigious bits of government, they have proven almost immune to EU foreign policy cooperation and the creation of the EEAS. Few if any of the national diplomatic services have downsized as a result of Lisbon. ${ }^{47}$ If anything, they have tried to remain visible and relevant. Instances of bureaucratic politics result directly from the parallel existence of the EEAS and the national diplomatic services and a lack of clarity about the division of labour. ${ }^{48}$

The combination of the complex legal framework and political reality implies that the question of who is representing the EU is not always as straightforward as a cursory reading of the Treaties might suggest. The remainder of this chapter analyses different scenarios in order to better understand the mechanisms behind the process of EU representation in practice. It focuses subsequently on multilateral, bilateral and ad hoc EU external representation.

\section{EU EXTERNAL REPRESENTATION IN MULTILATERAL FORA}

The EU's representation in multilateral fora - understood to include both formal international organizations and international regimes - can take different forms, oscillating between full membership and observer status. ${ }^{49}$ This is the result of various legal and political factors, both inside and outside the EU. First of all, the EU's capacity to act on the international stage is a matter of competence. It is therefore no coincidence that full membership is mostly granted in international organizations dealing with issues falling within the scope of the EU's exclusive competence or within areas where extensive internal harmonization has taken place. ${ }^{50}$ However, there is no direct correlation between strong internal competences and strong participatory rights

\footnotetext{
46 P Pierson, Politics in Time: History, Institutions and Social Analysis (Princeton University Press 2004).

47 Balfour and Raik (n 6); Rosa Balfour and Kristi Raik (eds), The European External Action Service and National Diplomacies (European Policy Centre 2013).

48 R Adler-Nissen, 'Symbolic Power in European Diplomacy: The Struggle Between National Foreign Services and the EU's External Action Service' (2014) 40 Review of International Studies 657; Dijkstra (n 7); Dijkstra (n 40).

49 Jørgensen, Oberthür and Shahin (n 4); Jørgensen and Laatikainen (n 4); Kaddous (n 7).

50 F Hoffmeister, 'Outsider or Frontrunner? Recent Developments under International and European Law on the Status of the European Union in International Organisations and Treaty Bodies' (2007) 44 CML Rev 54.
} 


\section{Research handbook on the EU's common foreign and security policy}

in international organizations. ${ }^{51}$ This is due to the second variable, which is the statute of the international organization concerned. It determines whether or not the EU can participate and in which form. ${ }^{52}$ Whereas the EU may have the competence to be directly represented, the possibility to make use of this competence depends on the institutional framework of the respective bodies. ${ }^{53}$

The EU's status in international organizations also largely depends upon the position of third countries since unanimity, or at least a qualified majority, is normally needed to accept a formal role for non-state actors. Other countries should thus be convinced that direct EU representation is not against their interests. ${ }^{54}$ Finally, EU Member States are not always keen to give up their position in multilateral fora in favour of a unified EU representation. Membership remains a clear expression of national sovereignty and is deemed important to safeguard unilateral influence on the international stage. Member States are traditionally reluctant to accept a stronger role for the EU if it comes at the expense of their own representation. ${ }^{55}$ They want to keep their unilateral institutional channels open, allowing them a variety of institutional choices. Arguably, this is even more relevant in the area of CFSP, which is a traditional stronghold of Member State sovereignty, in comparison to non-CFSP contexts where EU external representation more logically follows from the EU's internal competences. Moreover, the most relevant international organizations dealing with CFSP matters, such as the UN, NATO or the Organization for Security and Cooperation in Europe (OSCE), are state centric. Individual Member States are members of these organizations on their own merits, not as part of some sort of broader EU external presence. ${ }^{56}$ As a result, attempts to upgrade the EU's direct representation face legal and political difficulties.

This is most clearly illustrated by the development of the EU's representation in the UN. ${ }^{57}$ Prior to the Lisbon Treaty, the rotating Presidency represented the EU for matters concerning the CFSP whereas the Commission represented the European Community. The abolition of the pillar structure and the introduction of new rules for external representation under primary EU law (cf. supra) triggered a revision of this arrangement. In particular, the replacement of rotating Presidency representatives with

51 J Wouters and A-L Chané, 'Brussels Meets Westphalia: The European Union and the United Nations' in P Eeckhout and M Lopez-Escudero (eds), The European Union's External Action in Times of Crisis (Hart Publishing 2016) 304.

52 Kaddous (n 7).

53 Wouters and Chané (n 51) 304.

54 J Sack, 'The European Community's Membership of International Organisations' (1995) 32 CML Rev 1234

55 ibid, 1232-1233.

56 Nevertheless, some formal and informal intra-EU coordination may take place. See, for instance, S Blavoukos and D Bourantonis, 'The EU's Performance in the United Nations Security Council' (2011) 33 Journal of European Integration 731; N Græger and KM Haugevik, 'The EU's Performance With and Within NATO: Assessing Objectives, Outcomes and Organisational Practices' (2011) 33 Journal of European Integration 743.

57 Laatikainen (n 5); E Drieskens, L Van Dievel and Y Reykers, 'The EU's Search for Effective Participation at the UN General Assembly and UN Security Council' in E Drieskens and LG Van Schaik (eds), The EU and Effective Multilateralism: Internal and External Reform Practices (Routledge 2014). 
EU institutional actors had important repercussions. Whereas the Presidency representatives could benefit from their state's UN member status to express the EU's position, this was not automatically guaranteed for the EU's institutional representatives. In line with the EU's observer status, the latter would only be allowed to intervene at the end of the debates and would face serious limitations regarding the circulation of official documents and proposals. To avoid such detrimental consequences, a diplomatic initiative resulted in the adoption of UNGA Resolution 65/276 aligning the rules for the participation of the EU in the work of the UN with the provisions of the Lisbon Treaty. 58

The new resolution allowed European Council President Van Rompuy to intervene for the first time in the General Debate of the UN General Assembly in September 2011. This was considered 'a major breakthrough in a forum where the promotion of national sovereignty continues to be a dominant factor'. ${ }^{59}$ Nevertheless, the process leading to the adoption of this new arrangement also revealed the limits and practical problems of the EU's representation in multilateral fora. In particular, it proved very difficult to convince third countries of the need to upgrade the EU's rights of representation. Countries from Africa and the Caribbean Community (Cariforum) feared that allowing greater participation by the EU might undermine the principle of equality among sovereign states and the intergovernmental character of the UN system. This opposition led to significant amendments in comparison to the initial draft of the resolution, watering down the EU's ambitions. ${ }^{60}$ The EU remains somewhat 'procedurally handicapped' within the UN system. ${ }^{61}$ For example, as the EU cannot vote in the UNGA, it also cannot give an explanation of a vote on behalf of the members.

Apart from the opposition from third countries, the implementation of Resolution 65/276 also encountered resistance from EU Member States. The United Kingdom, in particular, feared that the EU's direct representation might lead to an erosion of national competences. Accordingly, the British government actively resisted a so-called 'representation creep' ${ }^{62}$ This resulted in controversy about the right of EU delegations to deliver statements in the name of the EU in the area of shared competences. The United Kingdom insisted that such statements could only be made 'on behalf of the EU and its Member States' and not simply 'on behalf of the EU'. A compromise solution

\footnotetext{
58 PA Serrano de Haro, 'Participation of the EU in the Work of the UN: General Assembly Resolution 65/276' (CLEER Working Papers 2012/4) <http://www.asser.nl/media/1633/cleer 2012-4web.pdf> accessed 3 March 2017; J Wouters, J Odermatt and T Ramopoulos, 'The Status of the European Union at the United Nations General Assembly' in I Govaere, E Lannon, P van Elsuwege and S Adam (eds), The European Union in the World: Essays in Honour of Marc Maresceau (Brill 2014) 211.

59 Serano de Haro (n 58); see also Laatikainen (n 5) on all sorts of transitional arrangements and bureaucratic challenges for EU officials to represent the Union.

60 See Jan Wouters, Anna-Louise Chané and Jed Odermatt, 'Improving the EU's Status in the UN and the UN System: An Objective Without a Strategy?' in Kaddous (ed) (n 7) 52.

61 Wouters, Odermatt and Ramopoulos (n 58) 212.

62 UK Foreign and Commonwealth Office, Review of the Balance of Competences between the United Kingdom and the European Union, July 2013, 41, <https://www.gov.uk/government/ uploads/system/uploads/attachment_data/file/227437/2901086_Foreign_Policy_acc.pdf> accessed 3 March 2017.
} 


\section{Research handbook on the EU's common foreign and security policy}

was found in October 2011 when the Council adopted a document setting out the 'General Arrangements for EU statements in multilateral organisations'. ${ }^{63}$ This discussion is evidence of the importance of the alternative and parallel institutional channels that Member States want to keep in addition to EU representation.

The Council document provides some general principles and practical guidelines. Most notably, it addresses the UK's concerns in pointing out that the EU's external representation does not affect the internal division of competences. The EU can only make a statement when it is competent and after a common position has been agreed in accordance with the relevant Treaty provisions. ${ }^{64}$ The EU representation is to be exercised from behind the EU nameplate unless prevented by the rules of procedure of the relevant organization. Member States may complement the EU statements as long as they respect the principle of sincere cooperation. When Member States agree, EU actors can thus express statements relating to issues of national competence. In such instances, the statement will be prefaced by 'on behalf of the Member States'. In areas of shared competence, the prefix 'on behalf of the EU and its Member States' will be used and for statements referring exclusively to positions adopted in the EU framework, reference will be made to 'on behalf of the European Union'. Significantly, the guidelines provide that the latter practice includes the CFSP. ${ }^{65}$

The discussion surrounding the delivery of statements in multilateral fora revealed the key distinction between internal coordination and external representation. Once an EU position is adopted, this position is to be represented by EU actors externally on the basis of the division of labour foreseen in the Treaties. With respect to CFSP matters, this implies that the President of the European Council, the High Representative or the EU delegation take the floor on behalf of the EU. The Member States are bound to coordinate their action and to uphold the EU's positions whereas the High Representative shall organize this coordination. ${ }^{66}$ In practice, this implies that the EU delegations play a crucial role in ensuring 'on the spot' coordination. More than 1,000 annual coordination meetings take place in New York, Geneva and Vienna ensuring the coherence of the EU's position in the UN and the OSCE. ${ }^{67}$ For international conferences taking place in a location where there is no EU delegation, the Member State holding the Presidency may, on an ad hoc basis, chair the 'on the spot' internal coordination meetings. ${ }^{68}$

\footnotetext{
63 Council of the EU, 'EU Statements in multilateral organisations: General Arrangements', doc. 15901/11, 24 October 2011.

64 ibid.

65 ibid.

66 Art. 34(1) TEU.

67 M Schmidt, 'The Position of the European Union in the United Nations. A United Nations Perspective' in Kaddous (ed) (n 7) 35. D Spence, 'From the Convention to Lisbon: External Competence and the Uneasy Transition for Geneva Delegations' in Spence and Batora (eds) (n 5); L-E Lundin, 'Effective Multilateralism After Lisbon: The Added Value of the EEAS and the EU Delegation in Vienna' in Spence and Batora (eds) (n 5); Laatikainen (n 5).

68 European Commission, Internal Guidance Note for all Commission Services on External Representation, SEC (2012) 118, 10 February 2012.
} 
After some teething problems, ${ }^{69}$ it seems that the post-Lisbon arrangements are now more or less established. At the same time, the ambition to further improve the EU's status in international organizations has become more modest. The 2012 Barroso-Aston paper, for instance, called for a piecemeal approach, focusing on a limited number of organizations. ${ }^{70}$ However, as can be derived from the CJEU's judgment relating to the International Organisation of Vine and Wine (OIV), nothing prevents the Union from adopting a position to be defended on its behalf in a body set up by an international agreement to which it is not a party, even when not all Member States are a party. The only criterion is that the adopted position concerns an area of law which falls within the EU's competence. ${ }^{71}$ Even in a context where EU external representation is not an evident option, the Member States are therefore bound to respect their EU law obligations.

This also applies with respect to CFSP matters. Article 34(1) TEU provides that '[i]n international organisations and at international conferences where not all the member states participate, those which do take part shall uphold the Union's positions'. Accordingly, the Member States which are members of the Security Council are under a duty to keep the other Member States and the High Representative fully informed and to defend the positions and the interests of the Union. ${ }^{72}$ When the EU has a defined position, the EU Member States which sit on the Security Council must request that the High Representative be invited to defend the EU's position. ${ }^{73}$ This innovation of the Lisbon Treaty significantly increased the visibility of the EU and allowed the High Representative, and particularly the EU delegation, to intervene on various occasions. ${ }^{74}$

\section{BILATERAL EU EXTERNAL REPRESENTATION}

While EU external representation in multilateral fora has brought some specific challenges, such as voting and speaking rights, getting the appropriate hearing at the bilateral level has hardly been easier for the EU. Once again, we see significant variation in EU bilateral representation across the globe, which is not easily explained by the EU competences. ${ }^{75}$ Indeed, to understand how external representation on the

\footnotetext{
69 PM Kaczynski, 'Swimming in Murky Waters. Challenges in Developing the EU's External Representation', FIIA Briefing Paper 88, September 2011.

70 Communication to the Commission from the President in Agreement with Vice-President Ashton, Strategy for the progressive improvement of the EU status in international organisations and other fora in line with the objectives of the Lisbon Treaty, C(2012) 9420 final, 20 December 2012.

71 Case C-399/12 Germany v Council EU:C:2014:2258, paras 49-52.

72 D Marchesi, 'The EU Common Foreign and Security Policy in the UN Security Council: Between Representation and Coordination' (2010) 15 European Foreign Affairs Review 97; Blavoukos and Bourantonis (n 56); Drieskens, Van Dievel and Reykers (n 57).

73 Art. 34(2) TEU.

74 Laatikainen (n 5).

75 Some of the empirical examples in this section are also discussed in $\mathrm{H}$ Dijkstra, 'Non-exclusive Delegation to the European External Action Service' in Delreux and Adriaensen (eds) (n 45).
} 


\section{Research handbook on the EU's common foreign and security policy}

bilateral level plays out requires us to account for the host country, both in terms of its importance for individual Member States as well as its attitude towards the EU.

As noted earlier, the Commission has long had an extensive network of delegations in other countries. These were offices of the Commission, staffed by Commission officials, trying to implement European policies from trade to development and enlargement. As the permanent bases of the EU abroad, they also became focal points for issues such as press and public diplomacy. The hybrid nature of the Commission delegations, somewhere between technical offices and full-fledged embassies, obviously resulted in challenges with protocol and accreditation. For instance, the Commission staff member appointed as Head of Delegation could not be called an 'ambassador'. ${ }^{76}$ Considering the sizeable EU development budgets, it is clear that some of the counterparts would prioritize the Commission Head of Delegation over many of the national ambassadors.

The Lisbon Treaty was supposed to address some of these challenges. The purpose was to turn all the bilateral Commission delegations into upgraded EU delegations consisting of both Commission civil servants and seconded European diplomats. This transformation has taken a considerable time and has been uneven at best. That the EU has so many bilateral delegations across the world allows us to run medium or large analyses of external representation. Austermann has done just that. ${ }^{77}$ She shows how Commission delegations have been upgraded to EU delegations at 'different speeds'. One of her findings - that EU diplomacy is least centralized in major economic partners - is perhaps surprising from the perspective of the EU's exclusive competence in this area, ${ }^{78}$ but it is completely unsurprising when considering the significant interests of the individual Member States in places like Washington or Beijing. Particularly when host countries matter, the Member States are unlikely to let the EEAS and its delegations get in their way.

The significance of the host country for the individual Member States is also underlined by Balfour and Raik, who note that EU delegations have 'been relatively easy to establish in less important and peripheral locations where member states have fewer political interests at play ... The easiest cases are locations where one's own country has no representation.' 79 Indeed they find that Washington, Beijing, New Delhi, Moscow, Cairo and Tokyo are places where Member States want to avoid their bilateral channels being compromised.$^{80}$ Dijkstra argues that these are instances of what he calls 'non-exclusive delegation' where Member States have delegated to the EU delegations a role in bilateral representation, but this role is hardly exclusive and is (re)negotiated on a daily basis (not dissimilar to EU representation in multilateral fora) ${ }^{81}$

It is impossible to describe the local dynamics in all the countries where the EU maintains bilateral relations but scholars have analysed the nitty-gritty details of setting

76 Bruter (n 9); Ramses Wessel, 'Can the EU Replace its Member States in International Affairs? An International Law Perspective' in Govaere and others (n 58).

77 Austermann (n 6).

78 C Damro, 'Market Power Europe' (2012) Journal of European Public Policy 682.

79 Balfour and Raik (n 6) 44.

80 ibid; see also Austermann (n 6).

81 Dijkstra (n 75). 
up several EU delegations after the entry into force of the Treaty of Lisbon. ${ }^{82}$ It is worth highlighting some of their key findings because these findings show us the importance of local variables affecting EU external representation. To start with China, we have witnessed the appearance of an interesting de facto division of labour between the Member States and the EU. Whereas the Member States themselves are in fierce competition regarding trade promotion and investment, they collectively have been happy to leave the difficult political dossiers (arms embargo, climate change, human rights, intellectual property rights, the market economy status) to the EU. The EU has proved a convenient cover shielding the bilateral trading interests. This is in line with intra-EU principal-agent dynamics outlined above.

Austermann has analysed this intra-EU political dynamic in greater detail with respect to the institutionalization of the EU delegation in Beijing. She writes that '[d]espite the clearly upgraded political role, the EU Delegation cannot do away with $\ldots$ the diverging interests of member states. This makes it difficult to speak always with one voice in Beijing.' ${ }^{83}$ Indeed, the Member States were pleased to have the Head of Delegation speak about human rights, such as in the case of the detention of $\mathrm{Ai}$ Weiwei, but refused to allow him to speak on behalf of the whole EU. ${ }^{84} \mathrm{He}$ could only make a statement on his own behalf. It is clear from the Beijing example that Member States have different channels for bilateral representation and they use them strategically.

While the division of labour between the Member States and the EU institutions is thus critically important for bilateral representation, it is not the full story. As with the multilateral fora, one also needs to account for the local environment. A comparison between EU delegations in Washington and Moscow is instructive. ${ }^{85}$ The way in which the US and Russian administrations systematically play around with the corps diplomatique (in different ways) also affects how the EU is represented externally.

Maurer notes the diplomatic circus in Washington is a constant 'beauty contest' ${ }^{86}$ The ambition for diplomatic actors is to gain the attention of the US administration. As such, individual Member States have been deeply suspicious of any bilateral role of the EU delegation, particularly in the area of political and security affairs. ${ }^{87}$ While this finding seems paradoxical considering that in Beijing Member States delegated precisely such tasks, it shows the significance of the local environments. The EU delegation in Washington has tried to stick to core EU competences, such as transatlantic trade, and to ensure that the EU effort would serve the interests of the Member States. One example has been organizing briefing meetings with US counterparts for all EU diplomats at the same time. The US administration has been supportive of this. As Maurer and Raik write, 'in Washington it is difficult to reach a high-ranking official ... The US had actively pushed the idea of meeting all EU member states ... at

82 See particularly individual chapters in Spence and Bátora (n 6).

83 F Austermann, 'Towards One Voice in Beijing? The Role of the EU's Diplomatic Representation in China Over Time' (2012) 18 Journal of European Integration History 83, 101. 84 ibid.

85 H Maurer and K Raik, Pioneers of a European Diplomatic System: EU Delegations in Moscow and Washington (FIIA 2014).

86 H Maurer, 'Europe in America: An Upgraded EU Delegation in a Reinforced System of European Diplomatic Coordination' in Spence and Batora (eds) (n 5) 276.

87 ibid, 28. 


\section{Research handbook on the EU's common foreign and security policy}

the same time ... even before the Lisbon Treaty ... such exchanges with the EU28 have become standard practice.' 88

The environment in Moscow is quite different. The Russian effort has focused on divide-and-rule and, as such, Russian officials have not been keen to meet the EU28 collectively. ${ }^{89}$ Access is generally restricted and Moscow has had little interest in EU-level officials, preferring to deal with more high-level national (e.g. German) officials. Maurer and Raik note that this Russian attitude has pushed diplomats of the EU Member States closer together, ${ }^{90}$ particularly since the annexation of Crimea and the establishment of the EU sanctions regime in 2014. For our understanding of EU external representation more broadly, however, it is once again significant to account for this local environment in which bilateral representation takes place.

\section{AD HOC EU EXTERNAL REPRESENTATION}

While multilateral and bilateral diplomacy tend to be institutionalized, ad hoc forms of external representation may allow the EU institutions a greater presence. Yet what we have seen, particularly with respect to high-level mediation, is a variation of formats through which the EU and its Member States are represented. Indeed, there also seem to be important internal and external variables at play in relation to ad hoc forms of external representation. Furthermore, while ad hoc external representation implies one-off events, it often consists of a process of mediation, persisting for years and resulting in a strong degree of path dependence.

There is a relatively long tradition of EU representatives participating in ad hoc diplomacy. Perhaps most famously, the so-called 'Troika' consisting at the time of the rotating Presidency and its predecessor and successor sought to mediate in the erupting conflict in former Yugoslavia in 1991. ${ }^{91}$ Similarly, former Swedish Prime Minister Carl Bildt was the EU envoy and Vice-Chair of the Dayton conference in 1995, even though his position was informally undermined by the British and French representatives also present. ${ }^{92}$ These experiences, and the lack of EU success in the Western Balkans, provided direct input for the Treaty of Amsterdam of 1999, which established the position of the EU High Representative (a continuous position to assist the rotating Presidency) and codified the EU Special Representatives, who would be appointed by the Member States to give the EU representation in some of the world's most important conflicts.

The first High Representative, Javier Solana, was particularly active in terms of ad hoc external representation. Perhaps because the rules of ad hoc diplomacy are less set in stone, this was an area where he could make a name for himself. As High

88 Maurer and Raik (n 85) 13.

89 ibid.

90 ibid, 13-14.

91 Luxembourg foreign minister Jacques Poos, flanked by his Dutch and Italian counterparts, declared that 'The hour of Europe has dawned', cited in T Garton Ash, History of the Present: Essays, Sketches and Dispatches from Europe in the 1990s (Penguin Books 2000) 94.

92 R Holbrooke, To End a War (Random House 1998) 242; Dijkstra (n 75). 
Representative, Solana was instrumental - together with NATO Secretary-General Lord Robertson - in negotiating the OHRID peace agreement for the former Yugoslav Republic of Macedonia in 2001. From 2003, he became the negotiator on behalf of the international community with Iran on nuclear non-proliferation. This paved the way for the later 'successes' of Ashton and Mogherini. Solana's biggest coup, however, was securing a seat on behalf of the EU in the Middle-East Quartet in 2004. Importantly, he did not have to 'share' this seat with other European representatives. He was a full member together with the American and Russian foreign ministers as well as the UN Secretary-General.

That the 'appointment' of EU representatives in ad hoc external representation goes beyond formal competences is perhaps best illustrated by Solana's mediation during the Israeli-Lebanese war in 2006.93 The Member States were confused and divided but Solana simply stepped on a plane. Asked by reporters on the ground whether he would lead mediation attempts, he stated that 'I am not going to tell you about any potential way of solving [the conflict]. My visit today here is a visit of friendship, of solidarity and support.' ${ }^{94}$ Several days later, he was back in Brussels where he briefed the EU foreign ministers, who gave him a lead role with respect to mediation. The situation was different in 2008, when Russia intervened in Georgia, and the French President Nicolas Sarkozy put himself forward as the rotating Presidency in negotiating a peace deal. Solana travelled with Sarkozy to Moscow and Tbilisi, but was all but ignored. 95

When Lady Catherine Ashton succeeded Solana in 2009, there were questions as to whether she would continue such activism, as she had less diplomatic experience. Nevertheless, a significant dose of institutional path dependence allowed her to continue the role of the High Representative in the Quartet and the Iran negotiations. The Middle-East Quartet became significantly less important during her tenure due to a lack of developments on the ground but she put significant efforts into the Iran negotiations. Despite the fact that most observers were happy to see her leave Brussels in 2014, there was a suggestion to keep her on as the main negotiator to bring the Iran negotiations to a successful close. ${ }^{96}$ The new High Representative Mogherini indeed kept her on for another round of negotiations, but quietly replaced her soon afterwards to benefit from the eventual deal.

In addition to Iran, mediation in the conflict between Serbia and Kosovo provides a good example of ad hoc diplomacy. Initially, Finnish President Martti Ahtisaari represented the EU in negotiations with Serbia and Russia. ${ }^{97}$ Significantly, the appointment of Martti Ahtisaari as the EU mediator was an initiative of the German Council Presidency in 1999. It was not based on a formal procedure and, for this reason, his status and mandate always remained somewhat unclear. ${ }^{98}$ Moreover, the

\footnotetext{
93 Dijkstra (n 7).

94 Cited in ibid, 8.

95 ibid, 12-15.

96 L Norman, 'EU's Mogherini Appoints Catherine Ashton Special Adviser for Iran Talks' (Wall Street Journal, 5 December 2014) <https://www.wsj.com/articles/eus-mogherini-appointscatherine-ashton-special-adviser-for-iran-talks-1417808968> accessed 3 March 2017.

97 See Statement of the European Union on Kosovo, 31 May 1999, Bull. EU 1999-5, 1.3.18.

98 A-S Maass, EU-Russia Relations 1999-2015. From Courtship to Confrontation (Routledge 2016) 14.
} 


\section{Research handbook on the EU's common foreign and security policy}

Council had already formally appointed Wolfgang Petritsch as the EU Special Envoy to Kosovo. ${ }^{99}$ Notwithstanding this ambiguity surrounding the EU's representation, the negotiations between Ahtisaari and the Russian ambassador Chernomyrdin paved the way for the adoption of Security Council Resolution 1244. This provided for the departure of Serbian troops and the deployment of an international civilian and security mission.

After Kosovo's unilateral declaration of independence in February 2008, the EU played a crucial role in the process of reconciliation with Serbia. From 2011, under the leadership of Lady Ashton, the EEAS started a so-called 'facilitated dialogue' between Belgrade and Pristina. ${ }^{100}$ The EU's mediation efforts successfully resulted in a series of agreements concerning Kosovo's external representation (2012), the acceptance of key principles governing the normalization of relations (2013) and issues such as energy, telecoms, the status of the Serb-majority municipalities in Kosovo, and freedom of movement over the Mitrovica bridge (2015). It was an example of classic, tiresome, long-term diplomacy coupled with sweeteners, such as the EU candidate status for Serbia and the Stabilisation and Association Agreement (SAA) with Kosovo. Significantly, acting through the EU's institutional structures allowed the Member States to circumvent the delicate issue of recognition. This explains why the SAA with Kosovo was concluded by the EU alone and not by the EU and its Member States. ${ }^{101}$

While the EU institutions and their representatives have become serious actors in diplomacy, it is also important to point at some setbacks. The conflict between Ukraine and Russia clearly illustrates that the EU can only play a meaningful role if this is acceptable for all parties involved. When Ashton decided to fly to Kiev in January 2014 to mediate between President Yanukovich and the opposition, Russian President Vladimir Putin quickly dismissed her initiative. ${ }^{102}$ Subsequently, crisis diplomacy was conducted by the foreign ministers of France, Germany and Poland - the so-called 'Weimar triangle' - acting 'in close coordination' with EU High Representative Ashton. ${ }^{103}$

Following Russia's annexation of Crimea and the escalation of violence in the eastern part of Ukraine, the EU's institutional actors gradually became sidelined. At the Minsk I negotiations, the EU was represented by an unusual troika of Ashton, Trade Commissioner De Gucht and Energy Commissioner Oettinger. At the Minsk II negotiations, there were no EU institutional actors. Instead, the President of France and

\footnotetext{
99 Council of the EU, Joint Action 1999/239/CFSP in relation to the nomination of a special envoy for Kosovo [1999] OJ L89/1.

100 Bergmann and Niemann (n 1).

101 P van Elsuwege, 'Legal Creativity in EU External Relations: The Stabilisation and Association Agreement between the EU and Kosovo' (2017) 22 European Foreign Affairs Review forthcoming.

102 I Traynor, 'Vladimir Putin tells Brussels to stay out of Ukraine's political crisis', The Guardian (28 January 2014) <https://www.theguardian.com/world/2014/jan/28/vladimir-putinukraine-crisis-eu> accessed 1 March 2017.

103 German Ministry of Foreign Affairs, 'Crisis Diplomacy in Ukraine' <http://www. auswaertiges-amt.de/sid_51AEA11E8F938CD608E304986BFBDECA/EN/Aussenpolitik/Laender/ Aktuelle_Artikel/Ukraine/140219_Ukraine.html?nn=472730> accessed 1 March 2017.
} 
the Chancellor of Germany were represented. Switzerland, as the OSCE Chairman-inoffice, played an important coordinating role. This constellation reflected Russia's reluctance to let EU actors play a role in questions of security and foreign policy. Instead, the preference is for intergovernmental discussions under the so-called 'Normandy format', involving the leaders of Germany, France, Russia and Ukraine.

\section{CONCLUSION}

EU external representation remains a puzzle for all but the closest observers. Whereas the EU is represented in one conflict by someone from the EU institutions, in other conflicts several Member States may take a lead role, and in yet other conflicts there is no common EU representation and/or position to speak of. While academics have long been interested in the question 'who speaks for Europe?', they have failed to come up with definite answers. The Treaty of Lisbon, rather than solving this question once and for all, has created new challenges for EU external representation across the world. In this chapter we have not provided definite answers, but we have offered a new way of understanding EU external relations by analysing more explicitly the interaction of legal and political dynamics.

For us, it is clear that while the EU Treaties have increasingly expanded the scope for collective EU external representation by EU agents, most recently with the Lisbon Treaty, one needs to recognize that there is a range of internal and external political and legal dynamics that constrain and aid the ability of the EU to fully represent itself. For instance, the upgrading of the Commission delegations to EU delegations has been uneven, and the EU delegations have not yet reached their full potential. While some of these dynamics have previously been discussed in the academic literature (and been applied to individual case studies), it is worthwhile to comprehensively sum up the most important limits and enablers for EU external representation.

With respect to intra-EU politics, there is an important tension between the ability of the individual Member States to make their own institutional choices and their legal obligations to follow the EU line. Institutional choice by the Member States (whether they act unilaterally or through EU channels) when addressing cooperation problems is well discussed in the international relations literature, whereas legal scholars have been interested in loyal cooperation. Yet to fully understand how the trade-off works out in practice requires us to take an interdisciplinary point of view. Indeed, much of the discussion about 'representation creep' in the UN concerns political arguments dressed up in legal terminology. Alternatively, France and the United Kingdom have continually refused to be loyal Member States when it comes to the Security Council, citing their conflicting obligations under the UN Charter.

It is, however, not only about how to most effectively promote national interest or solve a cooperation problem. Member States have also been worried about agency drift by the EU agents. In addition, we have seen strong bureaucratic politics dynamics at play. National embassies in places such as Washington have been worried about losing access to local counterparts. The different rotating Presidencies across the multilateral fora have not been all too happy about giving up their own roles. At the same time, the Member States occasionally use EU representation strategically, for instance to shift the 


\section{Research handbook on the EU's common foreign and security policy}

blame. Beijing is a key location where the EU is in charge of addressing some of the more difficult dossiers.

What our overview of EU external representation has also shown is that we need to look beyond intra-EU legal and political dynamics. It is not sufficiently well understood in the current academic literature that a critical condition for effective EU representation is in fact external and has to do with the environment in which representation takes place. Simply put, other states should be willing to meet EU representatives. If they are not, there is little that the EU can do about it. The importance of such external conditions is perhaps most obvious when it comes to the EU's dealings with the great powers. The EU has had a particularly hard time dealing with Russia (be it over Georgia or Ukraine). Yet it is not just about power politics. In the UN context, other (weaker) regional groupings have been able relatively easily to frustrate efforts for more EU representation. The EU, as a non-state actor, remains the odd one out in a world of sovereign states and this significantly conditions its ability to externally represent itself. 